\title{
Fura-2 Measurements of Cultured Rat Purkinje Neurons Show Dendritic Localization of $\mathrm{Ca}^{2+}$ Influx
}

\author{
Philip E. Hockberger, Hsiu-Yu Tseng, and John A. Connor \\ Department of Molecular Biophysics, AT\&T Bell Laboratories, Murray Hill, New Jersey 07974
}

The specific objectives of this study were the following: (1) to characterize the types of calcium currents in cultured PCs using whole-cell voltage-clamp techniques; (2) using fura-2 imaging techniques, to monitor intracellular $\mathrm{Ca}^{2+}$ levels during application of high potassium, glutamate, or glutamate analogs; and (3) to evaluate the types of calcium channels contributing to the calcium fluxes using pharmacological blocking agents.

Voltage-clamp analysis of calcium currents proved to be difficult due to space-clamping problems. The latter was presumably due to the unfavorable geometry of cultured PCs. Nevertheless, we found no evidence for inward currents in cells bathed in TTX-TEA- $\mathrm{BaCl}_{2}$ saline. On the other hand, fura-2 measurements demonstrated that free $\mathrm{Ca}^{2+}$ levels were elevated in PCs following local application of either highpotassium saline or glutamate. When individual cells were injected with fura-2 and analyzed in TTX-containing saline, the $\mathrm{Ca}^{2+}$ elevation was usually greater in the dendrites. Since $\mathrm{Ca}^{2+}$ levels were not elevated in all dendrites of the same cell, the smaller responses in the soma were not simply due to volumetric differences. Together with the voltage-clamp results, the fura-2 data indicate that calcium channels were localized to certain dendrites.

Using selective calcium channel blockers, we found evidence for 2 types of calcium conductances in the dendrites of cultured PCs. The $\mathrm{Ca}$ conductance induced by high potassium was reduced in a dose-dependent manner by nifedipine $\left(E D_{50}=5 \times 10^{-7} \mathrm{M}\right)$, indicating that a high-threshold voltage-dependent calcium channel was present. The $\mathrm{Ca}$ response to glutamate (or NMDA) was reduced by 2-amino-5-phosphonovaleric acid $\left(E D_{50}=10^{-4} \mathrm{M}\right)$, as well as by nifedipine or $1^{-4} \mathrm{M} \mathrm{LaCl}_{3}$, indicating that both voltage-dependent and glutamate-coupled channels were opened by glutamate application.

Historically, the dendrites of neurons within the CNS were presumed to be electrically inexcitable, capable only of passive conduction of synaptic potentials (Eccles, 1964; Rall, 1976). In the 1970 s exceptions to this notion were described in hippo-

\footnotetext{
Received May 5, 1988; revised Nov. 4, 1988; accepted Dec. 19, 1988.

We wish to thank Drs. Angus Nairn and Paul Greengard of the Rockefeller University for supplying the G-kinase antibodies, and Dr. James Morgan of the Roche Institute of Molecular Biology for supplying the PEP antibodies. That part of this work not sponsored by AT\& T Bell Laboratories was supported by a grant from the Air Force Office of Scientific Research under contract F49620.

Correspondence should be addressed to Dr. Philip E. Hockberger at his present address: Department of Physiology, Northwestern University Medical School, 303 E. Chicago Ave., Chicago, IL 60611.

Copyright (C) 1989 Society for Neuroscience $0270-6474 / 89 / 072272-13 \$ 02.00 / 0$
}

campal pyramidal cells (Schwartzkroin and Slawsky, 1977; Wong and Prince, 1978) and in cerebellar Purkinje cells (PCs) (Llinás and Nicholson, 1971; Llinás and Hess, 1976; Hounsgaard and Yamamoto, 1979). Intradendritic recordings from these cells showed that dendritic spikes differed from somatic spikes in that the former had a greater calcium ion contribution (Wong et al., 1979; Llinás and Sugimori, 1980a, b). These results were obtained using either ion-substituted salines or pharmacological blocking agents. Specific ionic conductances and their properties were not evaluated under voltage clamp, nor was there any evidence as to what type(s) of calcium conductance contributed to the dendritic spikes.

Recently, Tank et al. (1988) have used fura-2 imaging techniques to show dendritic Ca elevation in individual PCs in cerebellar slices. Similar results have been reported by Ross and Werman (1987) using arsenazo III spectroscopy. In this report we describe fura- 2 measurements of cultured rat cerebellar PCs during high potassium or glutamate application. We found that $\mathrm{Ca}^{2+}$ elevation in cultured PCs was localized in the dendrites even when these stimuli were applied to the soma. Since voltage-clamp measurements showed no evidence for a calcium conductance in the soma, the $\mathrm{Ca}$ responses were most likely generated in the dendrites. We also present pharmacological evidence for 2 types of calcium conductance in the dendrites of PCs: a voltage-dependent nifedipine-sensitive type and a glutamate-activated APV-sensitive type. These results support and extend our understanding of the role of calcium ions in dendritic excitability in these cells.

\section{Materials and Methods}

Cell cultures. All cells were dissociated from embryonic stage 1 (E20E22) and grown for at least 2 weeks in high-potassium medium, as described in the preceding paper (Hockberger et al., 1989). This was sufficient time to allow for the development of electrical excitability and glutamatc responscs.

Electrophysiology. We used whole-cell patch-recording techniques as described by Hamill et al. (1981). The equipment and procedures have been described previously (Hockberger et al., 1987). All recordings were carried out at room temperatures $\left(19-22^{\circ} \mathrm{C}\right)$. Whole-cell current records were not corrected for leakage or capacitative currents since only qualitative measurements were intended.

Iontophoresis electrodes were filled with solutions containing $10 \mathrm{~m} \mathrm{M}$ HEPES buffer and $0.1 \mathrm{M}$ solutions of either glutamate $(\mathrm{pH} 7)$, kainate ( $\mathrm{pH}$ 5), quisqualate $(\mathrm{pH} 7)$, or NMDA $(\mathrm{pH} \mathrm{10)}$. The $\mathrm{pH}$ values were adjusted with either $\mathrm{HCl}$ or $\mathrm{NaCl}$ in order to ensure adequate solubility of the transmitter. Electrolytes in either neutral or acidic solutions were ejected using negative pulses, while basic solutions necessitated positive pulses as expected from the $\mathrm{p} K$ values of the predominant charged groups. Breaking currents of oppositc polarity werc cmploycd in sufficient amounts to prevent leakage of the agents from the iontophoretic electrodes. For some experiments, double-barrel electrodes were used to enable the testing of 2 agents on the same cell. Either thin-walled glass or theta glass microelectrodes (A-M Systems) were used and pulled 
on a Kopf puller at settings that gave electrodes resistances of $10-15$ $\mathrm{M} \Omega$ when filled with $3 \mathrm{M} \mathrm{KCl}$.

Cells were bathed in normal external saline containing the following composition (in mM): $130 \mathrm{NaCl}, 5.4 \mathrm{KCl}, 1.8 \mathrm{CaCl}_{2}, 1 \mathrm{MgCl}_{2}, 25$ glucose, 10 HEPES buffer adjusted to $\mathrm{pH}$ 7.6. Patch electrodes were filled with internal saline containing (mM) $140 \mathrm{KCl}, 2 \mathrm{MgCl}_{2}, 1 \mathrm{CaCl}_{2}, 10 \mathrm{EGTA}$, 10 HEPES buffer adjusted to $\mathrm{pH}$ 7.2. High-potassium electrodes were filled with either 50 or $170 \mathrm{~mm} \mathrm{KCl}$ in TTX saline and delivered using positive pressure. Stock solutions of nifedipine were prepared by dissolving it in acetone and storing it at $4^{\circ} \mathrm{C}$ in the dark (i.e., wrapped in aluminum foil). Experimental solutions of nifedipine and 2-amino-5phosphonovaleric acid (APV; Sigma, St. Louis, MO) were prepared in normal external saline.

Immunocytochemistry. In this report we have used immunostaining techniques to help us to identify cultured PCs following either electrophysiological recording or fura-2 analysis. Data collected from positively stained PCs formed the basis for most of the Results. In those cases where staining was not used to verify cell identity, we based our assessment on morphological criteria (see Hockberger et al., 1989), as well as on similarities with results obtained from PCs that were identified through staining. Cells were marked by etching a circle in the substrate surrounding the cell with a microelectrode. Marked cells were fixed and stained for either peptide-19 (PEP) or cyclic GMP-dependent protein kinase (GK), as described in the preceding paper. Staining for PEP was preferrable because it was found to be a more selective stain for cultured PCs (see Hockberger et al., 1989). Although GK staining, which was done before PEP antibodies were available, stains both PCs and granule cells, the latter were much smaller and could therefore be distinguished from PCs by size (see Hockberger et al., 1989).

Fura-2 imaging. The imaging system we employed has been described in detail elsewhere (Connor, 1986; Connor et al., 1987). Briefly, this system uses a charge-coupled device (CCD) camera coupled to an inverted epifluorescence microscope (Zeiss IM-35). Cells were injected with the $\mathrm{Ca}^{2+}$ indicator dye fura-2 and photographed through the microscope during short exposures to UV illumination. Images of dye fluorescence at $500 \mathrm{~nm}$ were captured on the CCD camera, then stored and processed using a PDP-11/73 computer with associated graphics and computer interface boards. Ratio images were formed by dividing pixel by pixel the fluorescent intensity values following 340 and 380 $\mathrm{nm}$ excitation ( $250 \mathrm{msec}$ exposures). For enhanced resolution, ratio intensity values were assigned different colors that were then converted to calcium concentrations using a standard calibration curve (see Connor et al., 1987). The ratio images were displayed on a high-resolution TV monitor (Sony), and either photographed directly or analyzed numerically for differences in absolute intensities.

All cells were injected with dye using thin-walled glass microelectrodes pulled on a Brown-Flaming puller (Sutter Instrument Co., San Francisco, CA). Microelectrode resistances were 25-35 M 2 when filled with $3 \mathrm{M} \mathrm{KCl}$ and evaluated in saline solution at least $10 \mathrm{~min}$ after pulling. The tips of the injection electrodes were filled with a concentrated solution of $6 \mathrm{~mm}$ fura-2 (potassium salt; Molecular Probes, Eugene, OR), dissolved in distilled water that had been passed through a Milli-Q ultrafiltration system (Millipore Corp., Bedford, MA). Distilled water that had not been filtered was contaminated with enough calcium ions to completely quench the dye. After the tip of the microelectrode was sufficiently filled with fura-2, the remainder of the electrode was backfilled with $0.3 \mathrm{M} \mathrm{K} \mathrm{SO}_{4}$.

The resistances of fura- $2 / \mathrm{K}_{2} \mathrm{SO}_{4}$-filled microelectrodes typically exceeded $100 \mathrm{M} \Omega$ and were therefore unsuitable for intracellular recording. Nevertheless, they were useful for penetrating and filling cells with dye. On several occasions simply pressing the electrode tip up to the cell membrane resulted in sufficient loading of cell bodies and processes. The latter method usually required 5-10 min before enough dye had entered the cell to clearly see the processes, whereas electrode penetration filled cells within seconds. All imaging experiments were performed at $30-32^{\circ} \mathrm{C}$.

\section{Results}

\section{Voltage-clamp analysis of cultured Purkinje cells}

We attempted to analyze the calcium currents in cultured PCs using whole-cell voltage-clamp procedures. However, as one might expect from the cell morphology (cf. Fig. 8, preceding paper), it was difficult to clamp these cells. This was particularly
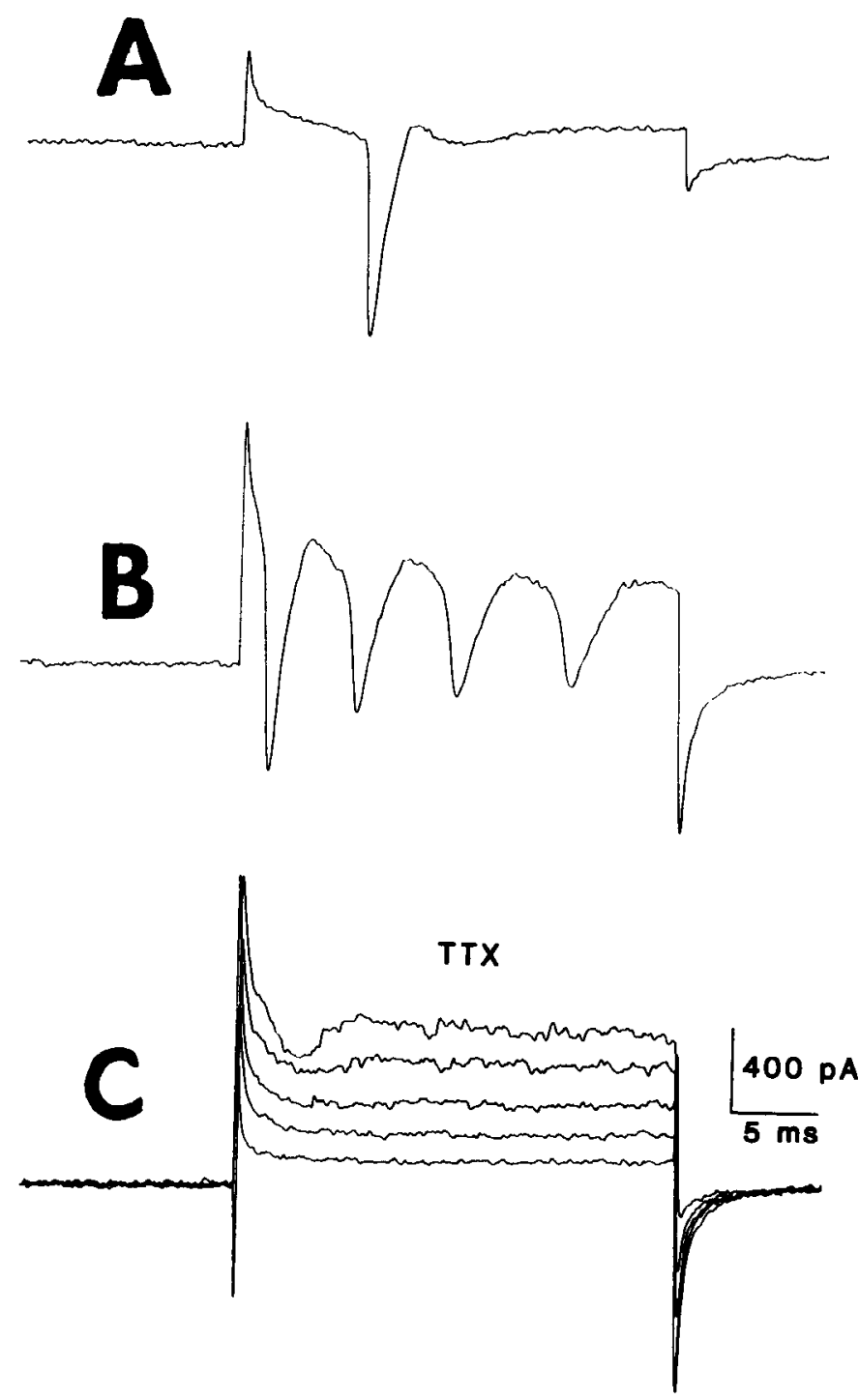

Figure 1. Current records from a cultured Purkinje cell ( 58 DIV) held at $-60 \mathrm{mV}$ and stepped to $-40 \mathrm{mV}(A)$ and $0 \mathrm{mV}(B)$. The delayed $(A)$ and multiple $(B)$ inward currents were indicative of currents generated in unclamped regions of the cell. These currents presumably originated in the axon since they were eliminated in $0.3 \mu \mathrm{M}$ TTX (C).

evident when making measurements in normal saline. For example, Figure $1 A$ shows a typical recording of membrane current during a voltage step from -60 to $-40 \mathrm{mV}$. After a relatively long latency, an inward current was generated followed by a small outward current. Stepping voltage more positive, e.g., to $0 \mathrm{mV}$, elicited multiple inward and outward currents (Fig. $1 B$ ). The long latency and oscillating currents in Figure 1 are indicative of cells with electrogenic processes that were not adequately space-clamped during the voltage steps.

Since bathing cells in TTX effectively eliminated these large inward currents (Fig. 1C), we reasoned we might be able to detect hidden calcium currents in solutions containing TTX $(0.3$ $\mu \mathrm{M}$ ), TEA (10 mM), and $1.8 \mathrm{~mm} \mathrm{BaCl}_{2}$ (substituted for $\mathrm{CaCl}_{2}$ ). This concentration of TEA completely blocks delayed outward currents in most mammalian neurons (Crill and Schwindt, 1983), and barium ions penetrate calcium channels (Hagiwara and Byerly, 1981; Brown et al., 1982) without activating calcium- 
A
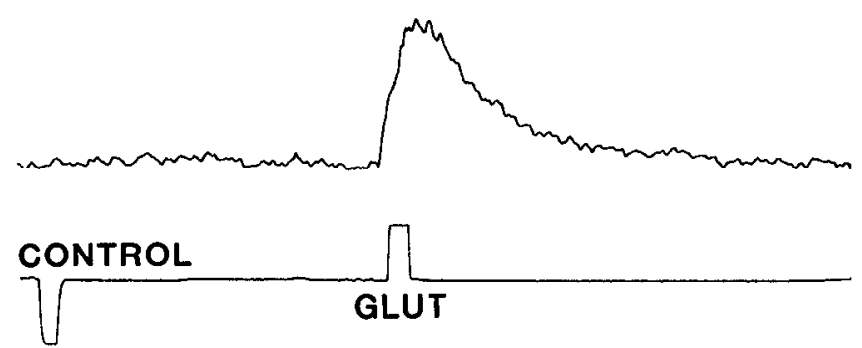

C

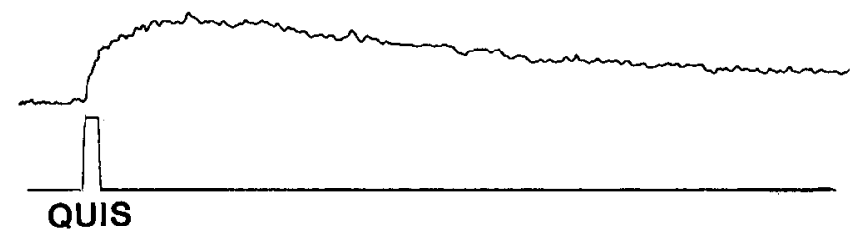

B
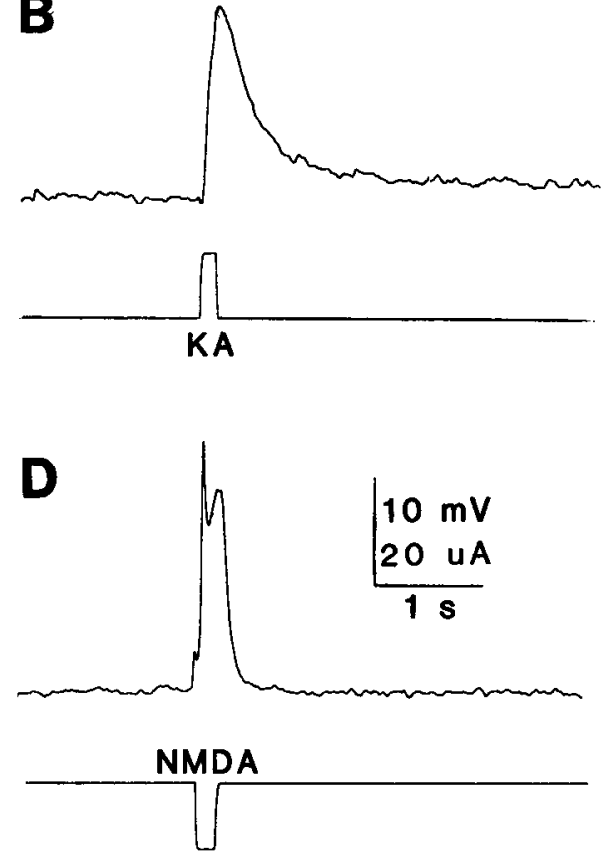

Figure 2. Membrane potential responses of a cultured Purkinjc ccll (22 DIV; GK-positive; $\mathrm{RP}=-60 \mathrm{mV}$ ) to iontophoretically-applied glutamate $(G L U T)$ and 3 analogs: kainate $(K A)$, quisqualate $(Q U I S)$, and NMDA. The agents were applied in pairs through double-barrel electrodes. Although the doses were similar, the amplitude and duration were different for each response.

dependent potassium currents (Meech, 1978; Ahmed and Connor, 1979; Schwindt and Crill, 1980). Holding membrane potential at $-40 \mathrm{mV}$ and stepping the voltage gradualy up to +60 $\mathrm{mV}$ gave no indication of an inward current in TTX-TEA-BaCl saline. This was the case even when cells were examined immediately upon electrode penetration, thus minimizing the possibility of calcium current washout $(n=4)$. The absence of an inward current suggests that either barium ions did not effectively penetrate the calcium channels in these cells, or else the steps were inadequate to activate calcium channel opening. The latter would occur if the channels were located in an unclamped region of the cell, e.g., in the dendrites, an interpretation that is supported by our Ca-imaging experiments below.

Electrophysiological responses to glutamate and glutamate analogs

We analyzed the membrane responses of cultured PCs to glutamate under current clamp. All cells examined $(n=14)$ were depolarized by glutamate when applied to the soma. When applied to the dendrites, large responses were often obtained up to $100 \mu \mathrm{m}$ from the cell body with regions of insensitivity in between. Elevating the iontophoretic electrode until no response could be obtained indicated that the diffusion radius of our typical doses (15-20 $\mu \mathrm{A}$ for $250 \mathrm{msec}$ ) was 20-25 $\mu \mathrm{m}$. Dendritic responses were also obtained in TTX saline suggesting that it was a direct effect on the cell and not due to synaptic activation $(n=4)$.

We compared the effects of glutamate with several glutamate analogs using double-barrel iontophoretic electrodes. One barrel contained glutamate and the other was filled with either kainate, quisqualate, or NMDA. Under these conditions, all cells responded to glutamate and kainate $(n=16)$, while only half displayed sensitivity to quisqualate and NMDA. A consistent finding was that the amplitude and duration of the analog re- sponses differed from that of glutamate even when the doses were assumed to be similar. Figure 2 shows the response to all 4 agents on the same cell (GK-positive) using identical protocols ( $20 \mu \mathrm{A}$ current for $250-300 \mathrm{msec}$ ). Although each agent induced a membrane depolarization, the duration of the responses differed: quisqualate $>$ glutamate $>$ kainate $>$ NMDA. The order was reversed when comparing the amplitude of the responses.

Since some glutamate responses display voltage dependence, due at least in part to extracellular $\mathrm{Mg}$ ions (Mayer and Westbrook, 1984; Nowak et al., 1984), we analyzed the somatic responses under voltage clamp. Figure 3 shows the currents evoked by each agent at 3 different holding potentials. To our surprise, the voltage dependence of the glutamate-evoked current was the opposite of what was found with the 3 analogs. That is, the glutamate currents decreased in amplitude at more negative holding potentials, while the analog-induced responses increased at negative potentials. The duration of the responses were not voltage-dependent over the range of potentials tested, i.e., -40 to $-80 \mathrm{mV}$. A more complete $I-V$ analyses was not attempted because (1) the receptors were also on the dendrites in regions that could not be adequately voltage-clamped, and (2) differences in agonist binding affinities could restrict diffusion of the agonists to distant receptors.

\section{Calcium imaging analysis of cultured Purkinje cells}

Microinjecting fura-2 into PCs enabled us to examine the $\mathrm{Ca}$ response of individual cells and their processes. Although highresistance microelectrodes were used in most cases to inject fura-2 (see Materials and Methods), application using wholecell recording was also tried. The latter approach created problems, though. After only a few minutes of recording with patch electrodes containing either 50 or $200 \mu \mathrm{M}$ fura- 2 (dissolved in internal saline without EGTA), cells required 5-10 min to recover from a Ca load, e.g., following a voltage step to $+20 \mathrm{mV}$. 
A

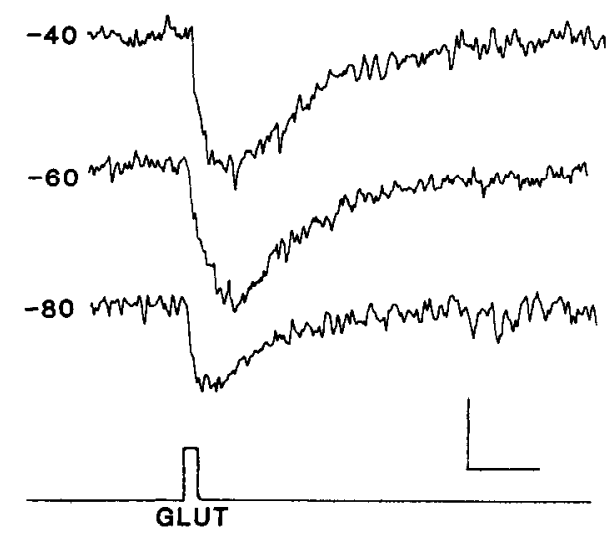

\section{C}

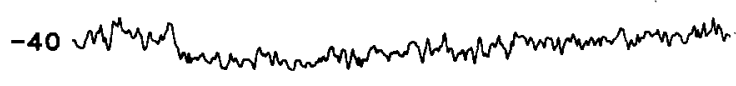

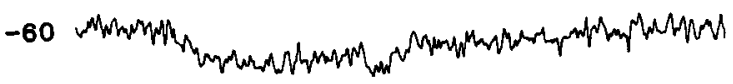

-80 morthery

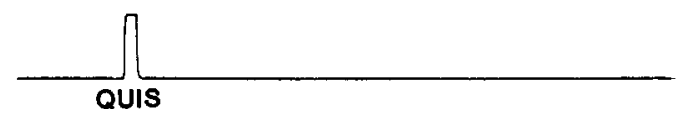

B

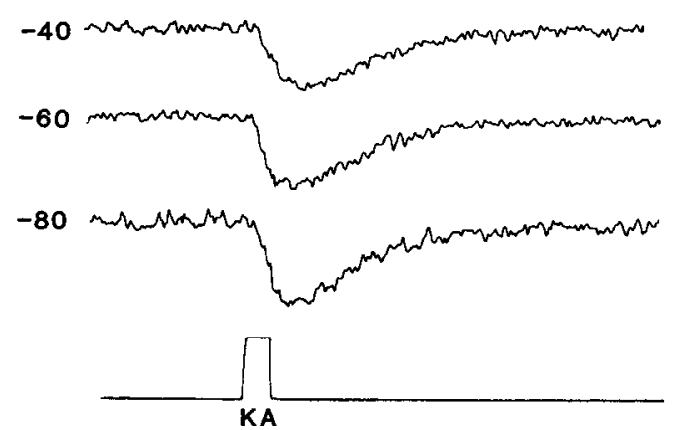

D

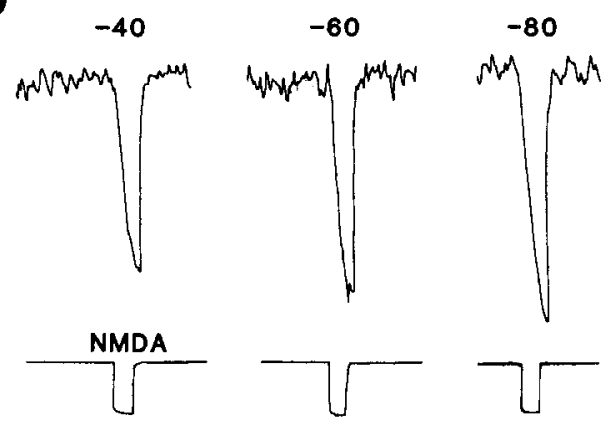

Figure 3. Currents elicited by glutamate and its analogs were compared under voltage clamp at 3 different holding potentials (same cell used for Fig. 2). The voltage dependence of the glutamate response was the opposite of thuse induced by the analogs. Note that the calibration scales in $B$ are different $(0.5 \mathrm{sec}, 100 \mathrm{pA})$ from the other records $(1 \mathrm{sec}, 50 \mathrm{pA})$, in order to show that the kainate currents were roughly twice as fast as the glutamate currents. The NMDA responses were even faster, and the QUIS responses much slower, than those evoked by glutamate.

With longer recordings, recoveries were absent. By comparison, cells in which the fura- 2 patch electrode was removed within 1 min after penetration were able to recover completely and repeatedly in less than $30 \mathrm{sec}$ following a Ca load (see below). We therefore resorted to comparing electrophysiological and $\mathrm{Ca}$ imaging responses separately in sister cultures.

\section{Dendritic localization of the Ca response}

Morphological data presented in the preceding paper (see Fig. 8 , preceding paper) indicted that processes between $2-4 \mu \mathrm{m}$ in diameter were most likely dendrites and that the thinner processes $(<1 \mu \mathrm{m})$ were axons. For our imaging studies we selected a threshold value that allowed us to monitor the light intensity of cell bodies and dendrites in the same image. Axons were absent since their smaller volume required higher threshold levels to be resolved. The threshold levels and magnification ( $\times 40$ objcctive) we sclcctcd gave the optimum resolution for responses in the cell bodies and proximal dendrites. Lower magnification (e.g., $\times 20$ ) enabled a larger view of the dendritic tree but reduced the spatial resolution of the $\mathrm{Ca}$ responses.

Initial imaging experiments demonstrated that cell bodies and proximal dendrites responded to either high potassium or glutamate with large $\mathrm{Ca}^{2+}$ elevations when bathed in normal saline. The responses were usually so large that the $380 \mathrm{~nm}$ image was difficult to resolve, impeding the formation of a ratio image. This problem was overcome by examining cells in TTX saline which blocked $\mathrm{Na}$ conductances and thus indirectly reduced the magnitude of the Ca response. Figure 4 shows a $C a$ response in a PC (GK-positive) during iontophoretic application of glutamate in TTX saline. The cell had 3 dendrites, 2 of which extended around and past a smaller cell (probably a granule cell). Prior to glutamate application, the resting level of free $\mathrm{Ca}^{2+}$ was uniformly around $120 \mathrm{~nm}$ (Fig. 4B). Following a $1 \mathrm{sec}$ application of glutamate, the $\mathrm{Ca}^{2+}$ concentration was immediately increased primarily in the upper-left dendrite (Fig. 4C). The elevation reached $200 \mathrm{nM}$ in the soma and 500-900 nM in the upper-left dendrite. The resting level in both cell compartments was partially restored when examined $15 \mathrm{sec}$ later (Fig. 4D), and it completely recovered after $30 \mathrm{sec}$ (data not shown).

It is tempting to speculate that the dendritic response reflects the location of glutamate receptors underlying a glutaminergic synapse between the nearby cell and the PC. However, another possible explanation for the differential distribution of the $\mathrm{Ca}$ response relates to differences in soma and dendritic volume. That is, a uniform $\mathrm{Ca}$ flux into a smaller compartment would be expected to give a larger concentration increase than the same flux into a larger compartment. Notice, though, that 2 other dendrites gave only a weak response, even though each was roughly the same diameter as the upper-left dendrite. Furthermore, the small elevation in these 2 dendrites displayed a concentration gradient away from the cell body, the opposite of what was found in the upper-left dendrite. This is especially revealing as it argues that no physical barrier was present at the soma-dendrite boundary. These observations are not consistent 


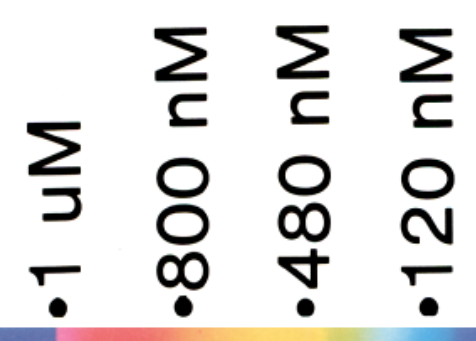

ด

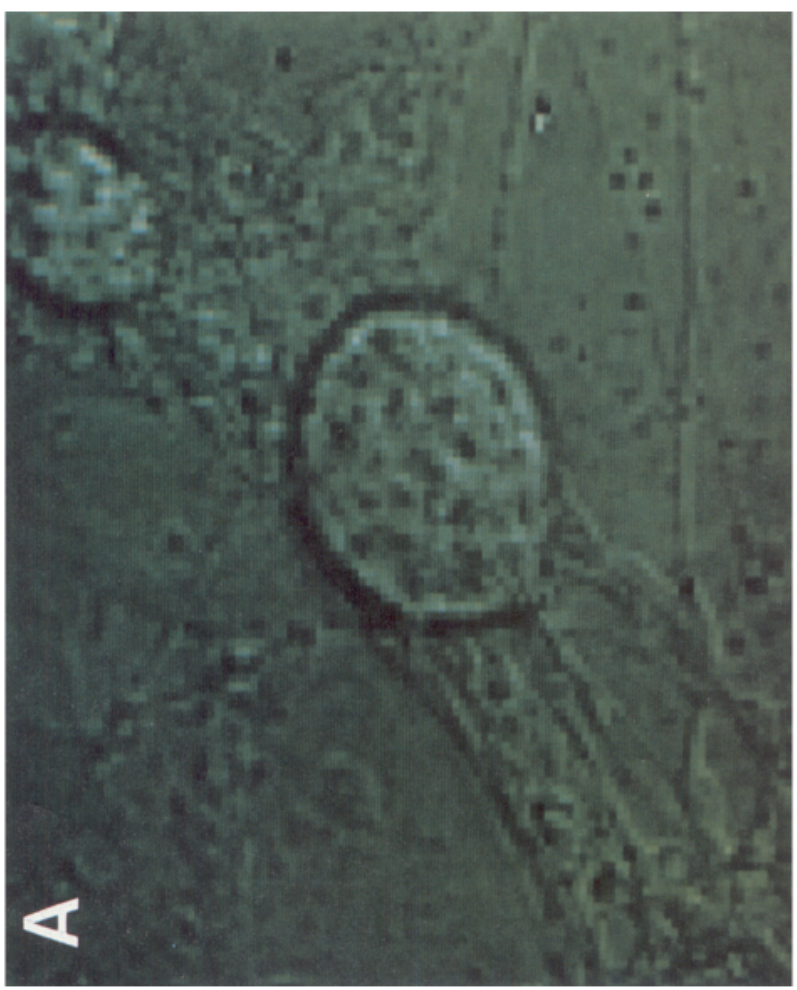

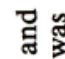

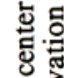

원

专

.

䄈焉
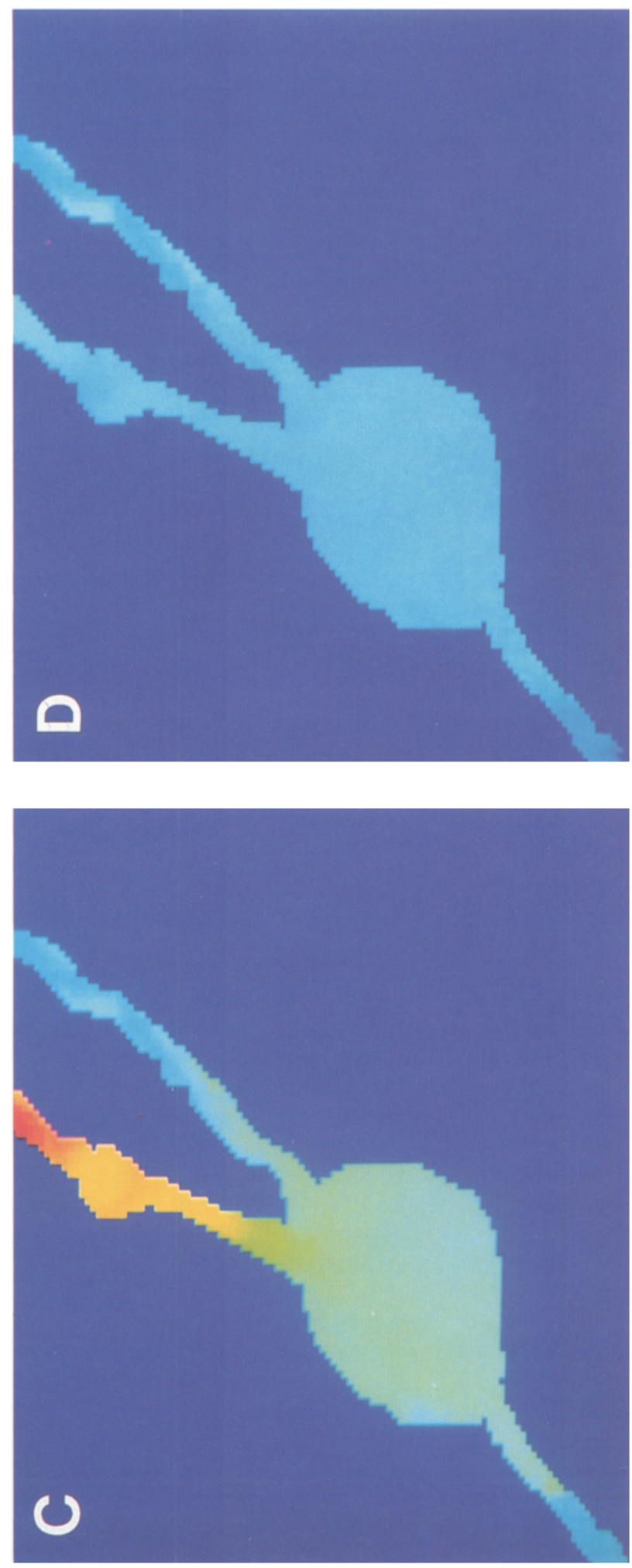

它

宛

品

.

要

完

这

물

ए.

:

焉

흔

굴

믐

율

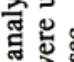

宇灵

Tิ

寻定

s n

38

讨

Uै.

当它

ร. 뜸

造

\%

䒠鬲

范

윽웅

돈.

可嵒

咥

중

象

굴.

응

过

至

궁.

๙

냄웜

㟧实

돌

옹을

․․․

$+\overline{8}$

总芯 

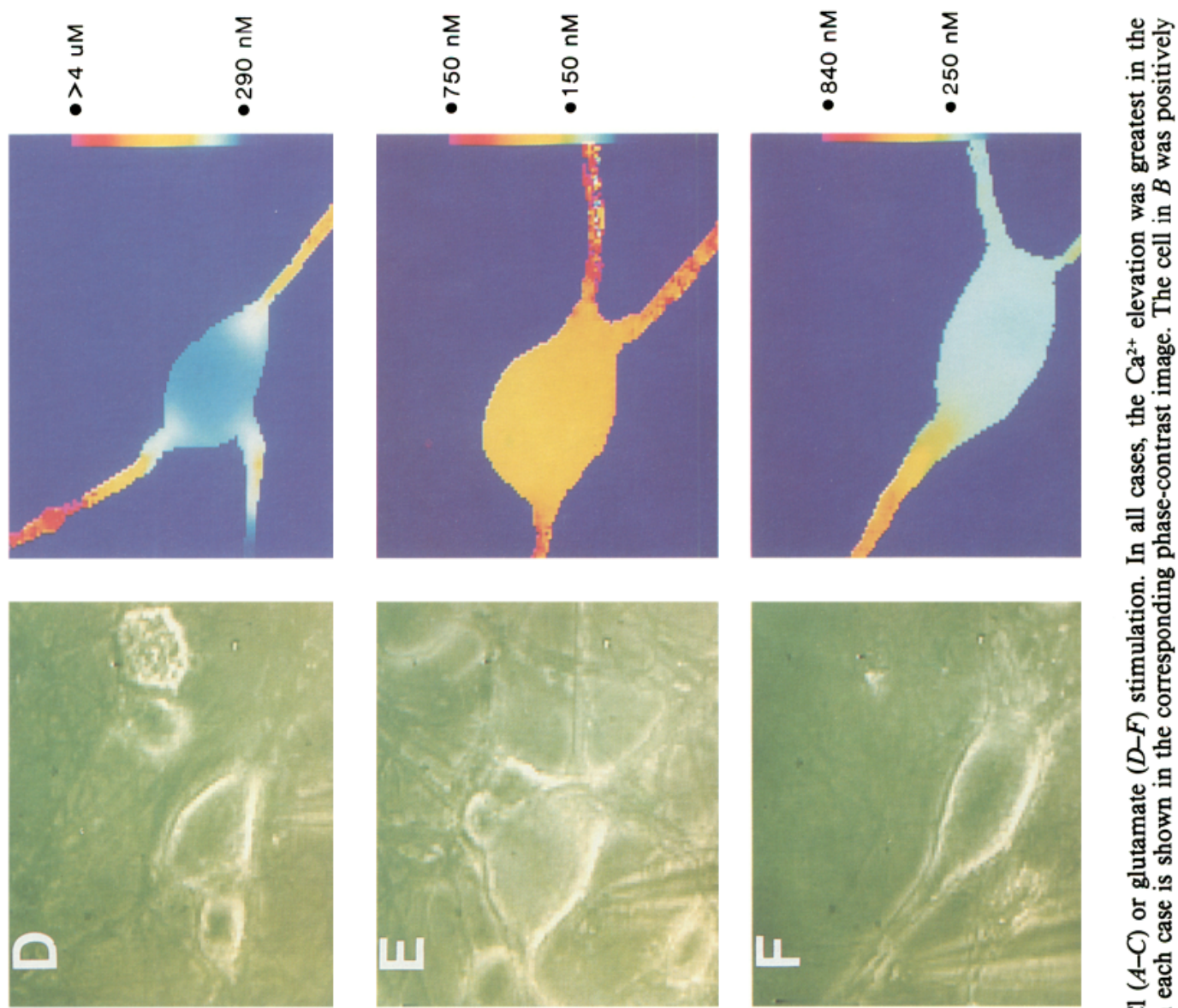

ธี่:

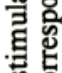

के

今。

氜

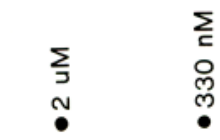

$\begin{array}{ll}\sum_{c} & \sum \\ \circ & 5 \\ \text { 이 } & 0 \\ \bullet & \bullet\end{array}$

\begin{tabular}{ll}
$\sum$ & $\sum$ \\
$\vdots$ & $\vdots$ \\
$\circ$ & 0 \\
\hdashline & $\bullet$
\end{tabular}

प्..
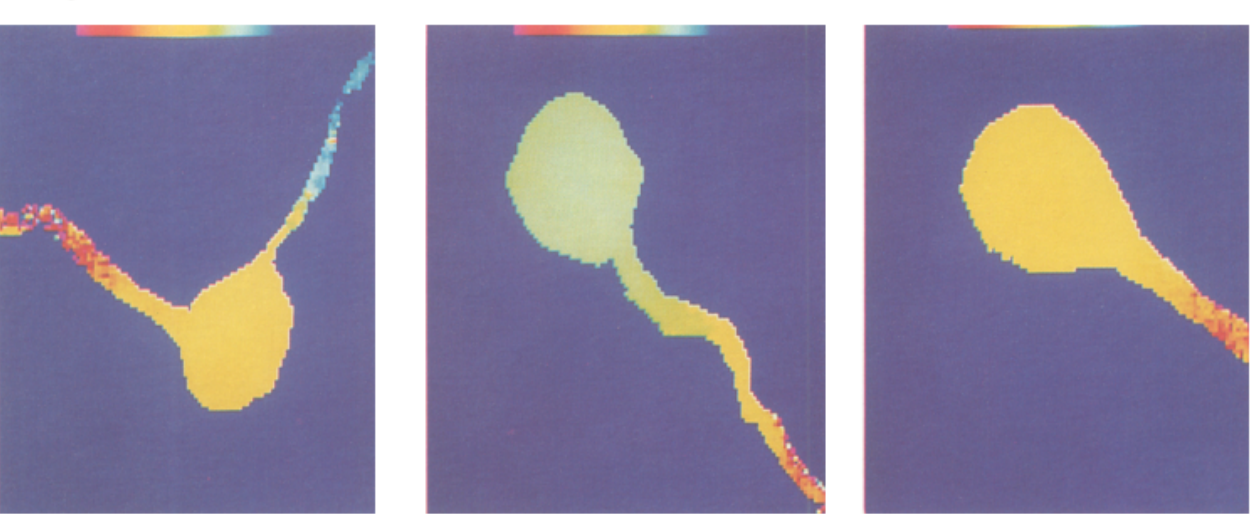

突范

in응

包

突急

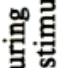

के

8

营:

品

范

害它

능

造

때
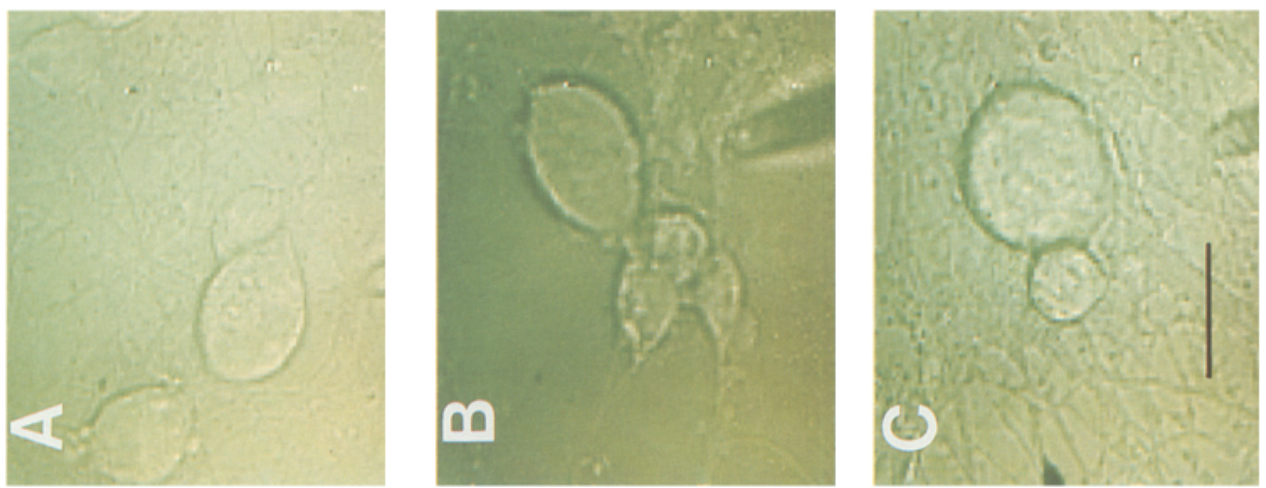

은

ำส ำ

5 .

동

8

政

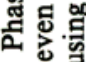

的逑

今. 


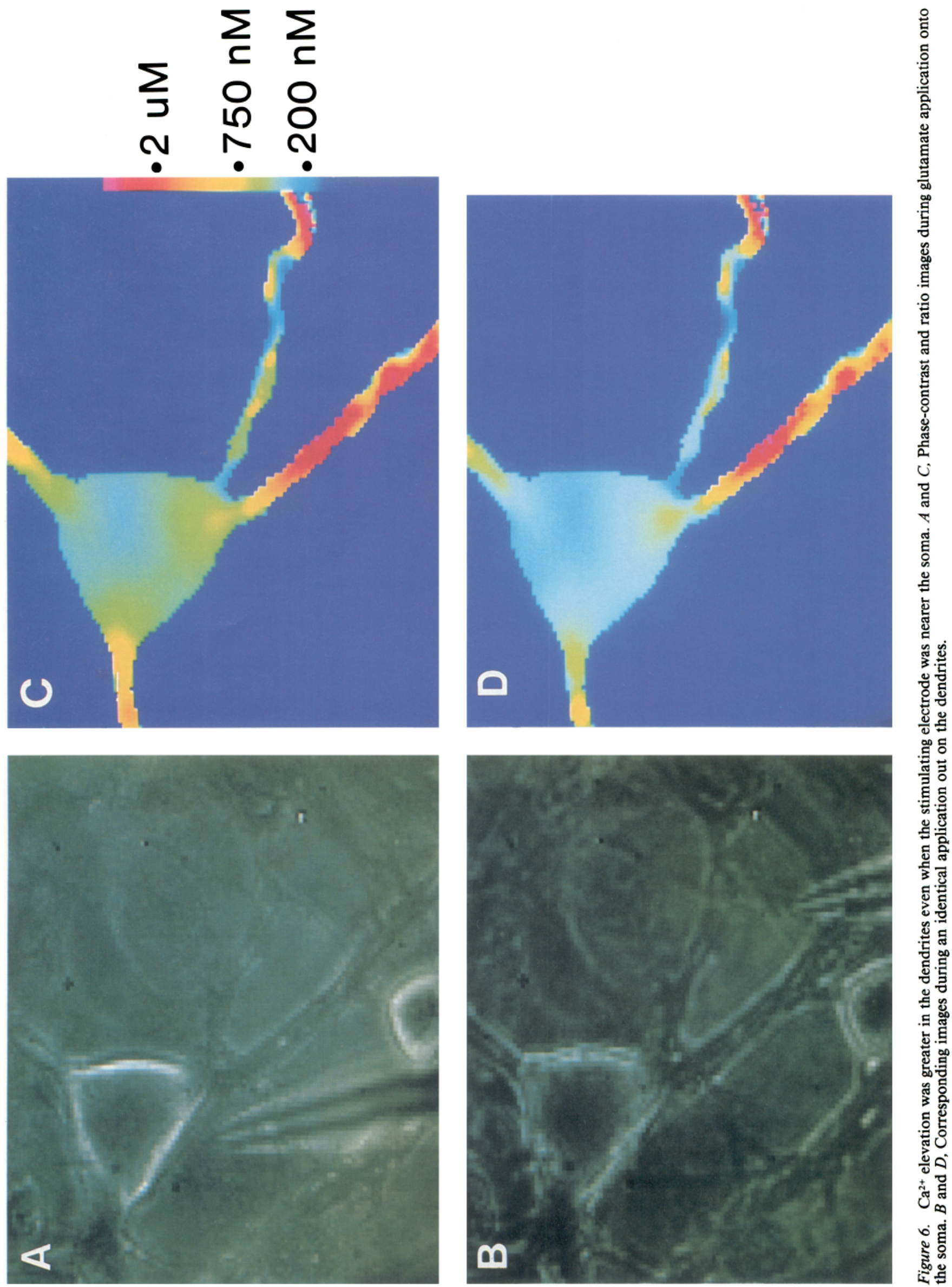



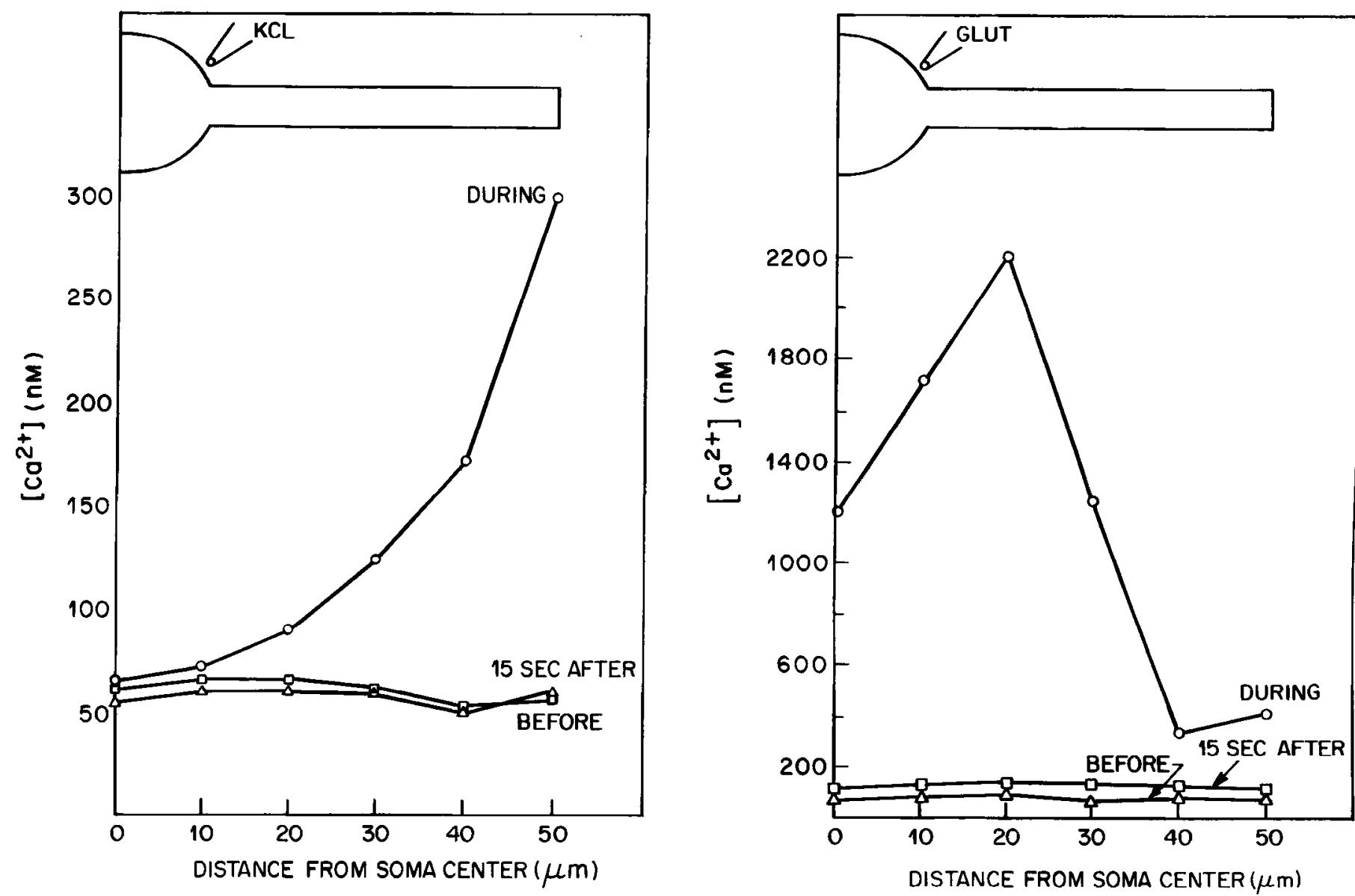

Figure 7. Graphic representation of the different Ca responses to $\mathrm{KCl}(l e f t)$ and glutamate (right) for the same cell (49 DIV; PEP-positive). The data are plotted versus distance from the soma center. The response to $50 \mathrm{mM} \mathrm{KCl} \mathrm{displayed} \mathrm{an} \mathrm{exponential} \mathrm{rise} \mathrm{along} \mathrm{the} \mathrm{proximal} \mathrm{dendrite} \mathrm{(left)}$ while glutamate evoked a larger response that peaked around $20 \mu \mathrm{m}$ from the soma center (right). Both responses recovered within 15 sec.

with the hypothesis that the higher $\mathrm{Ca}^{2+}$ elevation in the upperleft dendrite was simply due to its small volume.

Dendritic responses similar to the one shown in Figure $4 C$ were obtained following either glutamate or high $(50 \mathrm{~mm})$ potassium application in 18 out of 18 cells examined between $36-$ $55 \mathrm{~d}$ in culture (earlier times were not examined). Figure 5 shows 3 examples of each, where the peak dendritic $\mathrm{Ca}$ response was greater than the somatic response. The locations of the stimulating electrodes are shown in the phase-contrast images to the left of each ratio image. Figure $5, A-C$, was obtained during pressure application of high potassium through a blunt microelectrode. Figure 5, $D-F$, involved iontophoretic application of glutamate from a sharp microelectrode. Notice that not all dendrites were elevated by the same amount and that some were elevated less than the cell body. This was the case even when the stimulating electrode was closer to these dendrites than the others (Fig. 5, $A, D$ ).

This is more rigorously shown in Figure 6. Here, the glutamate electrode was first positioned near the cell body (cf. Fig. $6 A$ ). Notice that even when glutamate was applied directly onto the soma, the lower-left dendrite displayed the greatest $\mathrm{Ca}^{2+}$ elevation (Fig. 9C). Moving the electrode to a location between the 2 lower processes (Fig. 9B) still elicited a larger response in the lower-left dendrite (Fig. $9 D$ ). These results are also consistent with our electrophysiological measurements that demonstrated glutamate-sensitive areas on the dendrites (also see MacDonald et al., 1982).

Further support for this interpretation was found when we compared the response to high $\mathrm{K}$ and glutamate in the same PC. On the left-hand side of Figure 7 is the Ca response immediately after applying high $\mathrm{K}$ to the soma. The cell body remained low in $\mathrm{Ca}^{2+}$, while there was an exponential rise in the $\mathrm{Ca}^{2+}$ concentration throughout the first $50 \mu \mathrm{m}$ of the dendrite. The response recovered completely within $30 \mathrm{sec}$. Wholecell recordings showed that pressure application of $50 \mathrm{~mm} \mathrm{KCl}$ for $1-2$ sec depolarized the membrane potential of cells to roughly $-25 \mathrm{mV}$ for several seconds. For comparison, the right side of Figure 7 shows the response to glutamate. It displayed a Ca peak around $20 \mu \mathrm{m}$ down the dendrite, and the concentration gradient was similar in both directions away from the peak region. This result suggests a "hot spot" of $\mathrm{Ca}^{2+}$ entry, and it is similar to what is shown pictorally in Figure $6 D$ for another cell (red region in lower left dendrite). The differential responses to glutamate and $\mathrm{KCl}$ suggested to us that there may have been 2 types of Ca channels in the dendrite, one opened by high potassium (i.e., depolarization) and another by glutamate. This possibility was examined in greater detail using selective calcium channel blockers. 


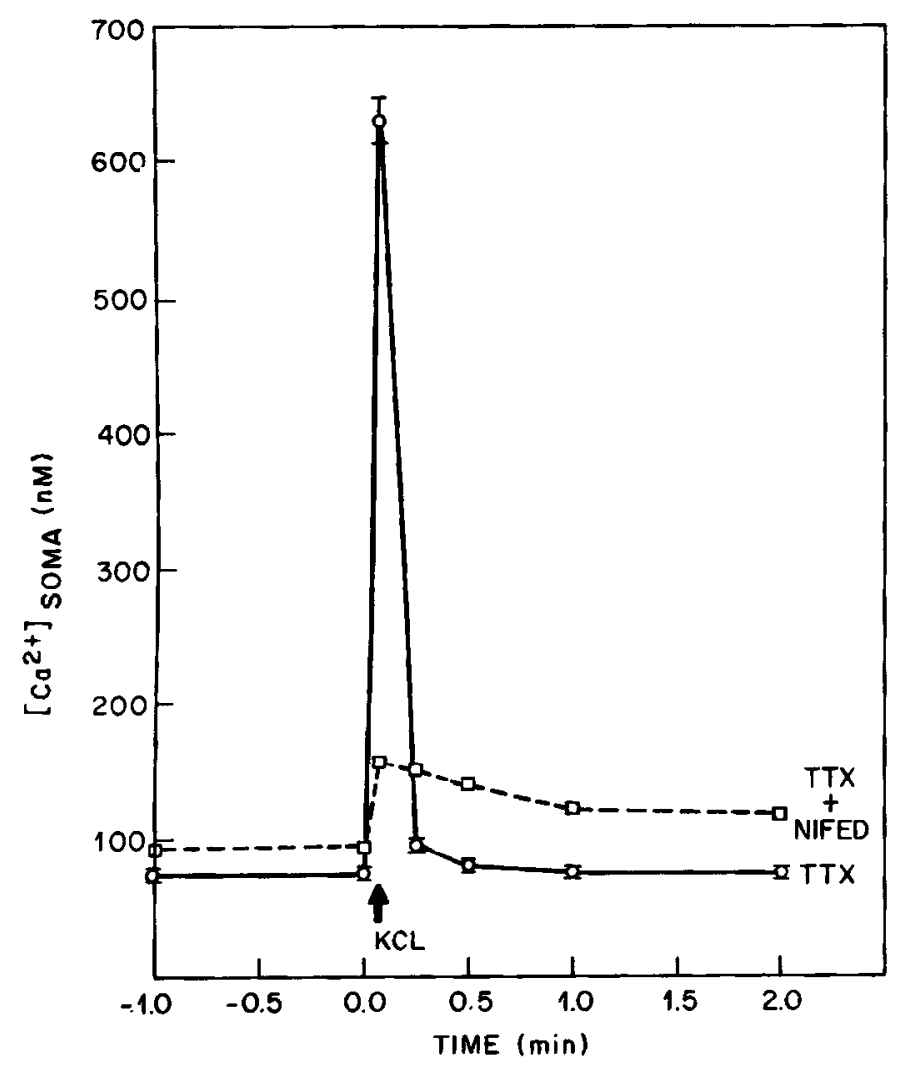

Figure 8. Ca response of the soma to $170 \mathrm{~mm} \mathrm{KCl}$ application is plotted in TTX before and after nifedipine ( 50 DIV). The response was virtually eliminated in $10^{-5} \mathrm{M}$ nifedipine. Similar results were found in the dendrites, although the control rcsponse was less uniform. An upward shift in the resting $\mathrm{Ca}^{2+}$ level was present after $10 \mathrm{~min}$ in nifedipine. The control values in TTX are the average of 2 consecutive responses.

\section{Pharmacological evidence for 2 types of Ca channels}

We have obtained pharmacological evidence for at least 2 types of calcium conductances in cultured PCs. The presence of voltage-dependent calcium channels was inferred from experiments using nifedipine and $\mathrm{LaCl}_{3}$. Evidence for calcium influx through glutamate-activated channels was deduced using NMDA and APV. We compared the peak amplitude of the $\mathrm{Ca}$ responses before and after drug application. The peaks of the responses were approximations of the actual elevations since the individual images were acquired over the entire period of stimulation (typically $1.5 \mathrm{sec}$ ). Nevertheless, the amplitudes we measured were quite reproducible displaying less than $5 \%$ differences between runs. We also focused upon changes in soma $\mathrm{Ca}^{2+}$ levels, instead of dendritic levels, because the former were more uniformly distributed, thus facilitating quantification of the responses.

In Figure 8, the $\mathrm{Ca}^{2+}$ level of a PC (GK-positive) was measured at the soma before, during, and after application of 170 mM KCl (a much larger dose than in Fig. 7). Companion electrophysiological measurements showed that this does of $\mathrm{KCl}$ depolarized the membrane potential to $0 \mathrm{mV}$ for several seconds. In the control run with $0.3 \mu \mathrm{M}$ TTX in the bath, $\mathrm{KCl}$ application raised the soma $\mathrm{Ca}^{2+}$ level from 80 to $630 \mathrm{nM}$, and the $\mathrm{Ca}^{2+}$ level was almost completely recovered within $15 \mathrm{sec}$ (the shortest time we measured). Bath application of $10^{-5}$ $M$ nifedipine in TTX saline increased the resting $\mathrm{Ca}^{2+}$ concen- tration of the cell but reduced the $\mathrm{Ca}$ response to $\mathrm{KCl}$ by approximately $80 \%$. The results were qualitatively similar for the dendrites, although dendritic responses were typically less uniform. The action of nifedipine was dose dependent with the average effective dose needed to reduce the response by $50 \%$ $\left(\mathrm{ED}_{50}\right)$ equal to $5 \times 10^{-7} \mathrm{M}(n=3)$.

The $\mathrm{ED}_{50}$ concentration of nifedipine also reduced the $\mathrm{Ca}$ response to glutamate indicting that part of this response involved activation of voltage-dependent calcium channels. Since high-threshold and low-threshold voltage-dependent $\mathrm{Ca}$ channels are reduced by $10^{-4} \mathrm{M} \mathrm{LaCl}_{3}$ (cf. Narahashi et al., 1987), we checked the $\mathrm{Ca}$ response to glutamate in $\mathrm{LaCl}_{3}$. Figure 9 plots the dendritic response showing that it was reduced by one-third in $10^{-4} \mathrm{M} \mathrm{LaCl}_{3}+0.3 \mu \mathrm{M}$ TTX compared with the response in TTX alone. Since $10^{-4} \mathrm{M} \mathrm{LaCl}_{3}$ is effective at eliminating both types of voltage-dependent calcium current (Narahashi et al., 1987), we presume that the remaining two-thirds of the $\mathrm{Ca}$ response was due to $\mathrm{Ca}^{2+}$ entering through glutamate-activated channels.

In spinal cord neurons glutamate induces a $\mathrm{Ca}$ flux through NMDA-activated channels. We therefore examined the response to NMDA in a PEP-positive cell (Figs. 10, 11). The cell response to NMDA was examined in $\mathrm{Mg}$-free saline containing TTX before and after adding the NMDA antagonist APV. In the control run, the Ca response to NMDA was larger in the dendrites than the soma (Fig. 10C), similar to what was found with glutamate. The recovery was complete by $15 \mathrm{sec}$ later (Fig. 10D). An identical dose of NMDA in the presence of $10^{-4} \mathrm{M}$ APV resulted in a reduced $\mathrm{Ca}$ response in both the soma and the dendrites (Fig. 10E). This response in APV did not recover as quickly as the control response (Fig. 10F). Similar results were obtained when glutamate was applied in the presence of APV suggesting that at least part of the glutamate-induced $\mathrm{Ca}^{2+}$ influx was through NMDA-activated channels.

An expanded record of these results is shown in Figure 11, where the average response for 2 such runs is illustrated. Again, the data are plotted for the soma, although the results for the dendrites were similar (see Fig. 10). Here we can see that APV reduced the average NMDA-induced response by approximately $60 \%$. There was also an unexpected increase in the resting concentration of free $\mathrm{Ca}^{2+}$ in APV + TTX saline, and a slower recovery of the response. Similar results were found when cells were analyzed in $\mathrm{LaCl}_{3}$ and nifedipine-containing salines (cf. Figs. 8, 9). This small increase in resting levels of $\mathrm{Ca}^{2+}$ may have contributed to the reduction in the $\mathrm{Ca}$ responses but cannot account for the large reduction seen in the presence of the agonists.

\section{Discussion}

Evidence for the dendritic localization of calcium conductancc in PCs has been reported previously using the cerebellar slice preparation. Hounsgaard and Yamamoto (1979) found that dendritic spikes, recorded extracellularly, were blocked by calcium channel blockers $\left(\mathrm{CoCl}_{2}\right.$ or $\left.\mathrm{MnCl}_{2}\right)$ but were unaffected by the sodium channel blocker TTX. Llinás and Sugimori (1980b) found similar results using intracellular recordings from $\mathrm{PC}$ dendrites. More recently, imaging methods have been used to show the dendritic localization of calcium elevation of PCs in slices (Ross and Werman, 1987; Tank et al., 1988). In this report, we present voltage-clamp and fura- 2 imaging data indicating that calcium conductances were also localized in the dendrites of cultured PCs. The voltage-clamp evidence is indirect and based 
upon the absence of calcium currents measured at the cell body, while the fura- 2 imaging results offer more direct evidence. This technique enabled us to deduce 2 types of calcium conductances in the dendrites of cultured PCs: A voltage-dependent, nifedipine-sensitive type (also called the high-threshold calcium conductance), and a NMDA-activated, APV-sensitive type. To our knowledge, this is the first evidence describing specific types of calcium conductances in PC dendrites.

We recognize that compartmentalization of the calcium response may have resulted in part from differences in the volume of dendrites and somata. That is, a uniform calcium influx would be expected to give a larger concentration change in regions of smaller volume, assuming all else was equal (e.g., calcium buffering, pumping, exchange). However, several observations indicate that volume considerations alone cannot account for the results we obtained. First, while some dendrites responded with $\mathrm{Ca}$ elevations higher than the cell body, other dendrites were lower (cf. Fig. 4). Second, this result was not dependent upon the placement of the stimulating electrode (cf. Fig. 6). Third, although individual responses were highly reproducible, different response profiles were measured in some dendrites with different types of stimulation (cf. Fig. 7). Each of these observations is not consistent with the interpretation that the localization of the response was simply due to volumetric considerations.

While our results are consistent with dendritic localization of the $\mathrm{Ca}^{2+}$ influx, asymmetries in cellular calcium buffering, pumping, and exchange could also contribute to the greater dendritic responses. While calcium pumping and exchange were probably too slow to effect the responses we measured, regional differences in calcium buffering could have influenced our measurements. Andrews et al. (1988) have shown that following prolonged high-potassium stimulation (30-120 sec) calcium accumulates in the cisterns of dendritic spines. Their results indicate that spine cisterns contribute significantly to the calcium buffering of PC dendrites. Calmodulin, a high-affinity calciumbinding protein, is also localized in the dendrites of PCs contributing to local buffering differences (Lin et al., 1981). However, greater buffering capacity in the dendrites would tend to reduce the size of the $\mathrm{Ca}$ responses relative to the soma. Thus, these observations would not explain the higher dendritic responses that we measured. The most likely explanation for our results is a combination of dendritic localization of calcium channels along with a smaller dendritic volume.

We were unable to record voltage-dependent calcium currents in cultured PCs using whole-cell voltage-clamp techniques. This was the case even under conditions that should have maximized the signal, i.e., in TTX-TEA- $\mathrm{BaCl}_{2}$ saline. However, Hirano and Ohmori (1986) have reported that calcium currents were present in cultured PCs in Na-free saline. There are several possible explanations for this difference between results. First, there was no indication given as to the frequency of their observation, and it is conceivable that differences between cells were encountered. Second, it was our experience with cultured granule cells that the location of membrane conductances changed during maturation (Hockberger et al., 1987). Thus, it may be that calcium conductances were present on PC somata during the first few weeks in culture but eventually move to the dendrites with further maturation. Evidence consistent with this interpretation has recently been provided by Regan (1987), who recorded $\mathrm{Ca}$ currents in developing PCs dissociated from 1- to 2-week-old rats. Another explanation is that the calcium cur-

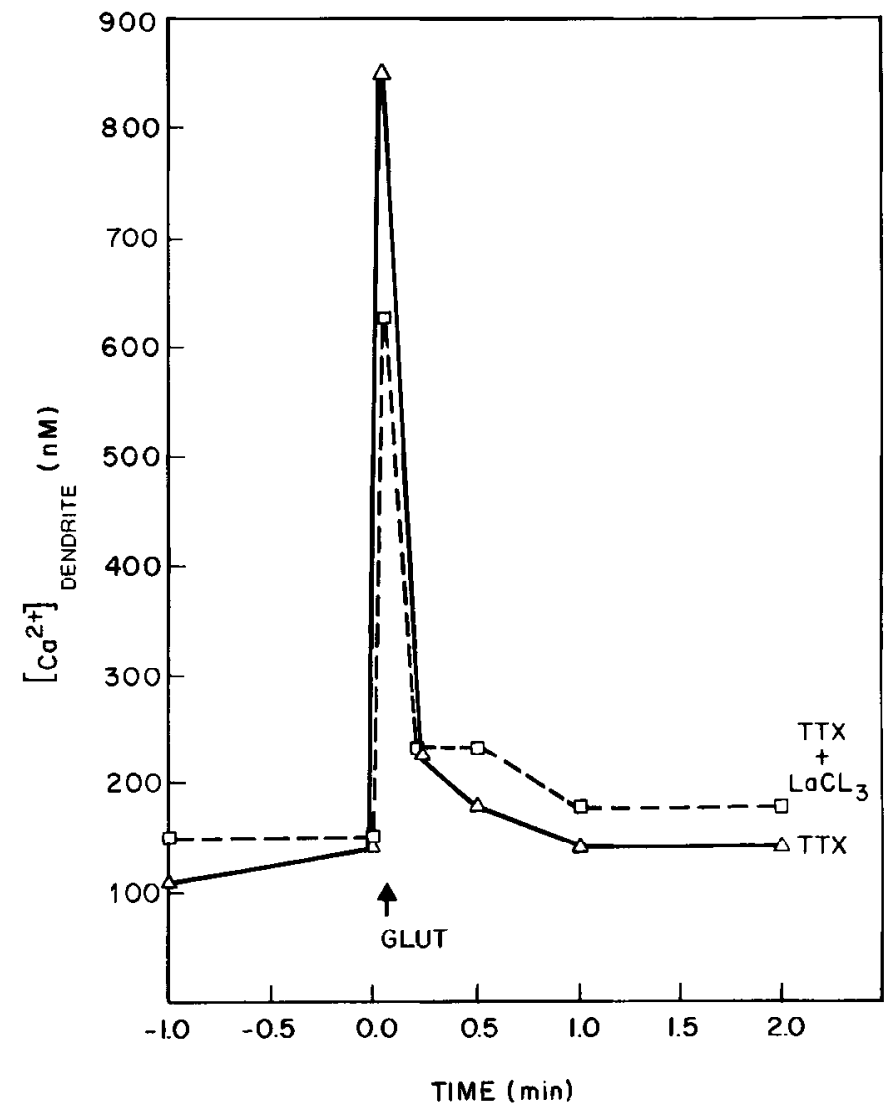

Figure 9. Glutamate evoked a dendritic $\mathrm{Ca}$ response in a cultured Purkinje cell (43 DIV; GK-positive) that was reduced by $10^{-4} \mathrm{M} \mathrm{LaCl}_{3}$.

rents recorded by Hirano and Ohmori were generated in the dendrites and propagated to the cell body. For the moment, it is simply not possible to distinguish between these possibilities since space-clamping problems in cells with processes make it difficult to interpret such voltage-clamp data.

Previous pharmacological studies either in vivo or in slices indicated that the glutamate analogs kainate and quisqualate depolarized PCs, while NMDA did not (Crepel et al., 1982, 1983; Kimura et al., 1985; Quinlan and Davies, 1985; Kano and Kato, 1987). However, more recently Lee et al. (1988) have shown that NMDA can excite, as well a inhibit, PCs in vivo. Furthermore Cull-Candy and Usowicz (1987) have presented single-channel evidence showing that NMDA receptors were present in cultured cerebellar macroneurons (presumably PCs), consistent with our results. We also found that NMDA induced a $\mathrm{Ca}^{2+}$ elevation in PCs similar to what has been found in cultured spinal cord neurons (MacDermott et al., 1986). In spinal cord neurons the natural transmitter is thought to be glutamate (Mayer and Westbrook, 1984). In PCs, though, it is unclear whether the NMDA response reflects a glutamate receptor or whether it acts via aspartate receptors (Wiklund et al., 1982, 1984; Kimura et al., 1985). The latter might explain why the voltage dependence of the NMDA-evoked current was different than the glutamate-evoked current (cf. Fig. 3).

The membrane depolarization induced by glutamate would be expected to elevate calcium through both glutamate-activated and voltage-dependent conductances. In fact this possibility is consistent with our imaging data which showed that the response to glutamate was reduced by nifedipine or $\mathrm{LaCl}_{3}$, agents known 

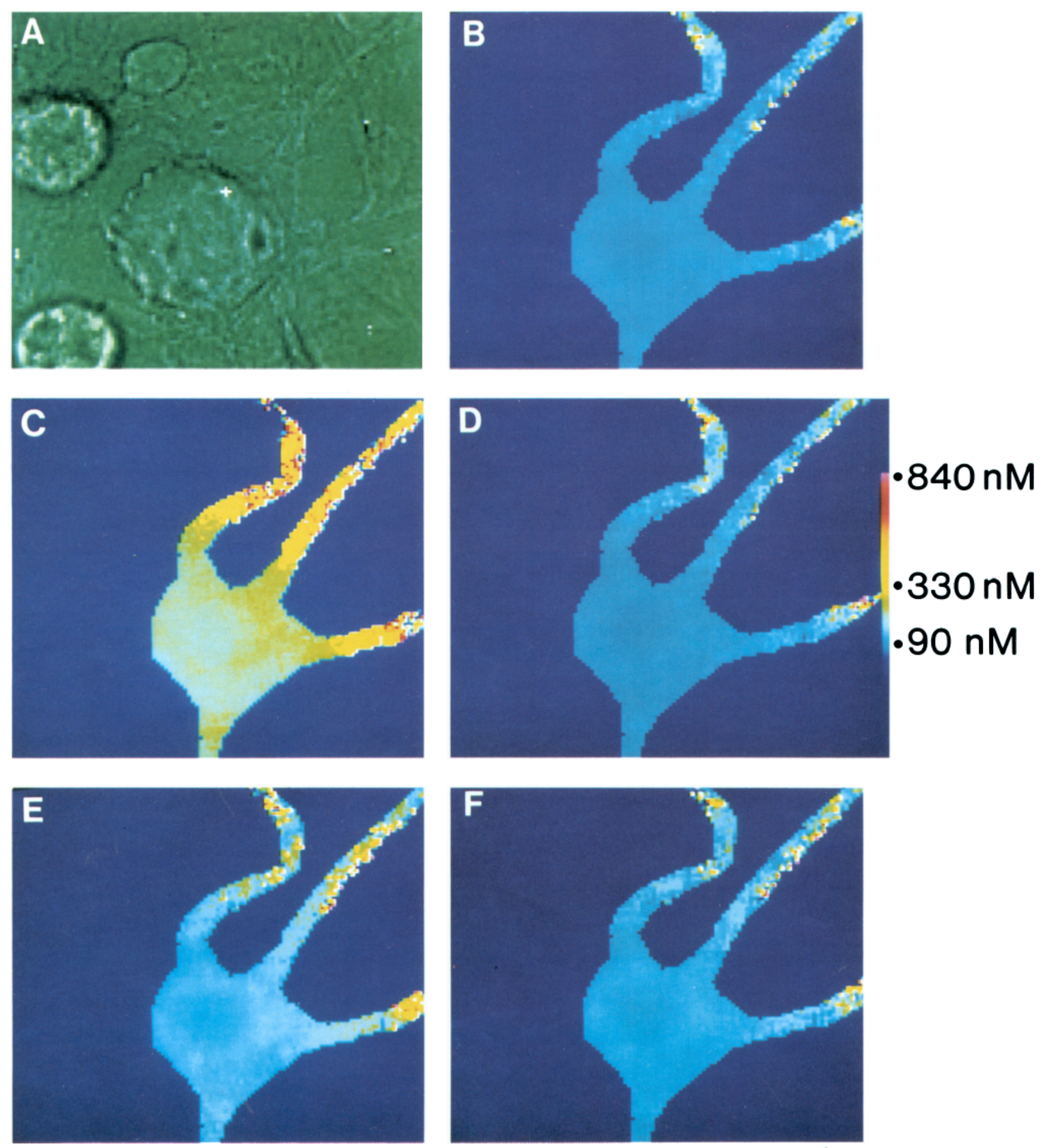

Figure 10. Ca response of a cultured Purkinje cell (48 DIV; PEP-positive) to NMDA application was reduced by $10^{-4} \mathrm{M}$ APV. $A$, Phase-contrast image showing cell and position of NMDA electrode. $B$, Ratio image prior to NMDA application. $C$, $\mathrm{Ca}^{2+}$ elevation during NMDA iontophoresis was primarily in the dendrites. $D$, Recovery $15 \mathrm{sec}$ later. $E$, Repeating the NMDA application in the presence of APV resulted in a reduced Ca response in both the soma and dendrites. $F$, Recovery $15 \mathrm{sec}$ later.

to block voltage-dependent Ca channels (Miller, 1987; Narahashi et al., 1987). However it is also possible that the dendritic response to glutamate resulted indirectly from a glutamate-induced depolarization of the soma. The latter could propagate to the dendrites causing voltage-gated Ca channels to open. This interpretation would not require dendritic localization of the glutamate receptors. However, 2 lines of evidence suggest this was not the case. One, our electrophysiological measurements demonstrated that receptors to glutamate and its analogs were present on both cell bodies as well as on dendrites. Electrophysiological studies of glutamate actions in vivo and in cerebellar slices also suggest that PC dendrites are more sensitive to glutamate than the cell bodies (Chujo et al., 1975; Hounsgaard and Yamamoto, 1979; Crepel et al., 1983). Two, the persistence 


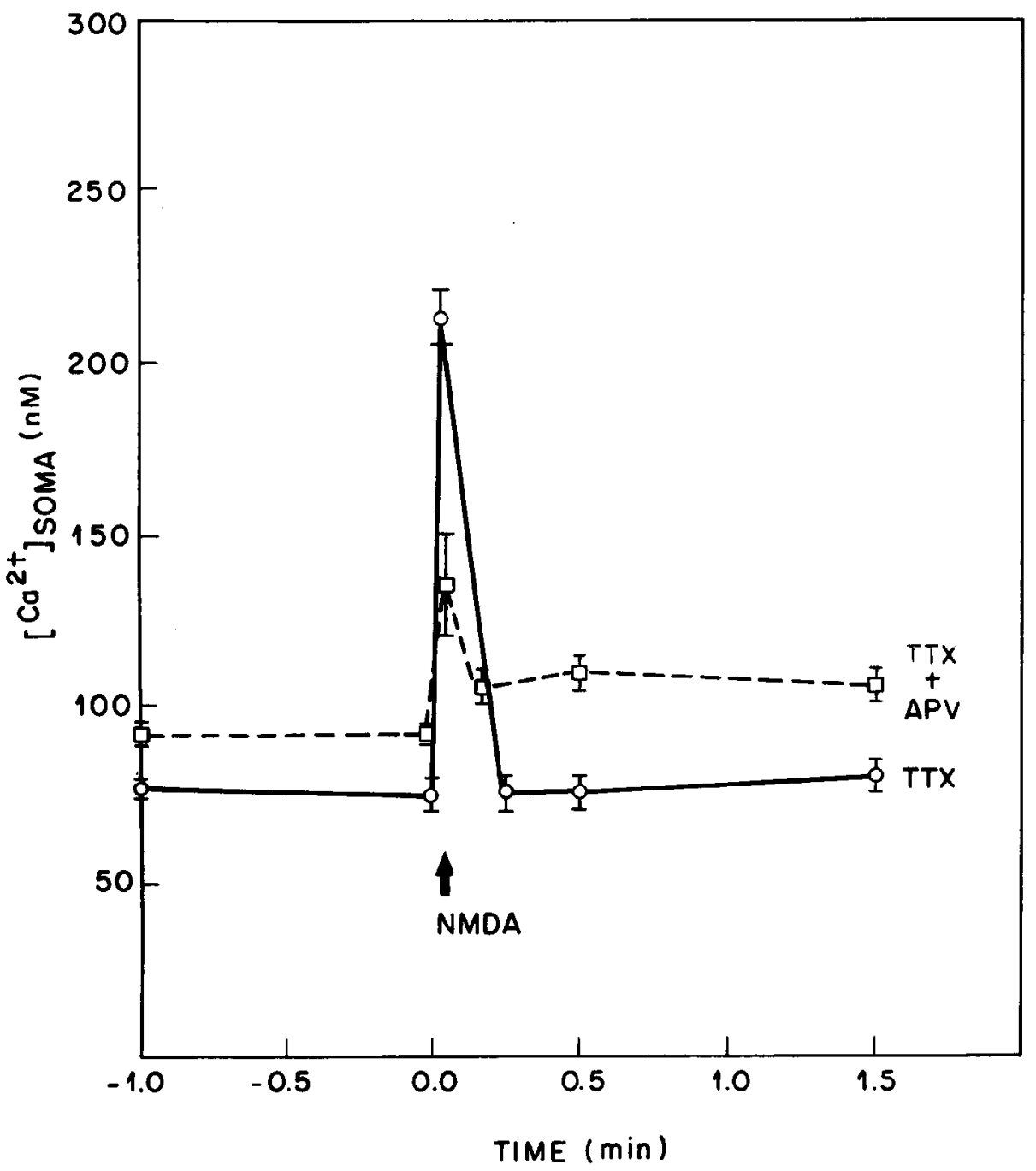

Figure 11. Graphic representation of the soma Ca response (same cell as Fig. 10) before and after APV perfusion. Each data point represents the average for 2 consecutive runs in control (TTX) and experimental (TTX + APV) salines. of the glutamate-induced calcium elevation in $\mathrm{LaCl}_{3}+\mathrm{TTX}$ argues that glutamate-activated channels were present on the dendrites.

We conclude by emphasizing that the dendritic localization of the $\mathrm{Ca}$ response was obtained in PCs dissociated from embryonic cerebellar and maintained in high potassium (25 mM) media. That is, not only did it occur in the absence of the normal cerebellar architecture, but it developed in the presence of a persistent depolarizing stimulus. These conditions make it difficult to arguc that cxternal forces alone could be responsible for directing the localization and expression of Ca channels. We therefore hypothesize that endogenous factors also play a role in this process. It has been shown that PCs in mutant mice devoid of granule cells do not display dendritic Ca-spikes (Crepel et al., 1984). Since granule cells were present in our cultures, a test of our hypothesis would be to determine whether dendritic localization of calcium occurs in their absence.

\section{References}

Ahmed, Z., and J. A. Connor (1979) Measurement of calcium influx under voltage clamp in molluscan neurones using the metallochromic dye arsenazo III. J. Physiol. (Lond.) 286: 61-82.

Andrews, S., R. Leapman, D. Landis, and T. Reese (1988) Activitydependent accumulation of calcium in Purkinje cell dendritic spines. Proc. Natl. Acad. Sci. USA 85: 1682-1685.
Brown, A., H. Camerer, D. Kunze, and H. Lux (1982) Similarity of unitary $\mathrm{Ca}^{2+}$ currents in three different species. Nature 299: 156-158.

Chujo, T., Y. Yamada, and C. Yamamoto (1975) Sensitivity of Purkinje cell dendrites to glutamic acid. Exp. Brain Res. 23: 293-300.

Connor, J. A. (1986) Digital imaging of free calcium changes and of spatial gradients in growing processes in single, mammalian central nervous system cells. Proc. Natl. Acad. Sci. USA 83: 6179-6183.

Connor, J. A., H.-Y. Tseng, and P. Hockberger (1987) Depolarizationand transmitter-induced changes in intracellular $\mathrm{Ca}^{2+}$ of rat cerebellar granule cells in explant cultures. J. Neurosci. 7: 1384-1400.

Crepel, F., S. Dhanjal, and T. Sears (1982) Effect of glutamate, aspartate, and related derivatives on cerebellar Purkinje cell dendrites in the rat: An in vitro study. J. Physiol. (Lond.) 329: 297-317.

Crepel, F., J. DuPont, and R. Gardette (1983) Voltage clamp analysis of the effect of excitatory amino acids and derivatives on Purkinje cell dendrites in rat cerebellar slices maintained in vitro. Brain Res. 279: 311-315.

Crepel, F., J. DuPont, and R. Gardette (1984) Selective absence of calcium spikes in Purkinje cells of staggerer mutant mice in cerebellar slices maintained in vitro. J. Physiol. (Lond.) 346: 111-125.

Crill, W., and P. Schwindt (1983) Active currents in mammalian neurons. Trends Neurosci. 6: 236-240.

Cull-Candy, S., and M. Usowicz. (1987) Glutamate and aspartate activated channels and inhibitory synaptic currents in large cerebellar neurons grown in culture. Brain Res. 402: 182-187.

Eccles, J. C. (1964) The Physiology of Synapses, Springer-Verlag, Berlin.

Grynkiewicz, G., M. Poenie, and R. Tsien (1985) A new generation of Ca indicators with greatly improved fluorescence properties. J. Biol. Chem. 260: 3440-3450. 
Hagiwara, S., and L. Byerly (1981) Calcium channel. Annu. Rev. Neuroscience 4: 69-125.

Hamill, O., A. Marty, E. Neher, B. Sakmann, and F. Sigworth (1981) Improved patch-clamp technique for high resolution current recording from cells and cell-free membrane patches. Pfluegers Arch. 391: $85-100$.

Hirano, T., and H. Ohmori (1986) Voltage-gated and synaptic currents in rat Purkinje cells in dissociated cultures. Proc. Natl. Acad. Sci. USA 83: 1945-1949.

Hockberger, P., H.-Y. Tseng, and J. A. Connor (1987) Immunocytochemical and electrophysiological differentiation of rat cerebellar granule cells in explant cultures. J. Neurosci. 7: 1370-1383.

Hockberger, P., H.-Y. Tseng, and J. A. Connor (1989) Development of rat cerebellar Purkinje cells: Electrophysiological properties following acute isolation and in long-term culture. J. Neurosci. 9: 22582271 .

Hounsgaard, J., and C. Yamamoto (1979) Dendritic spikes in Purkinje cells of the guinea pig cerebellum studied in vitro. Exp. Brian Res. 37: 387-398.

Kano, M., and M. Kato (1987) Quisqualate receptors are specifically involved in cerebellar synaptic plasticity. Nature 325: 276-279.

Kimura, H., K. Okamoto and Y. Sakai (1985) Pharmacological evidence for L-aspartate as the neurotransmitter of cerebellar climbing fibres in the guinea pig. J. Physiol. (Lond.) 365: 103-119.

Lee, M., H. Strahlendorf, and J. Strahlendorf (1988) Differential effects of N-methyl-D-aspartic acid and L-homocysteic acid on cerebellar Purkinje neurons. Brain Res. (in press)

Lin, C.-T., J. Dedman, B. Brinkley, and A. Means (1981) Localization of calmodulin in rat cerebellum by immunoelectron microscopy. J. Cell Biol. 85: 473-480.

Llinás, R., and R. Hess (1976) Tetrodotoxin-resistant dendritic spikes in avian Purkinje cells. Proc. Natl. Acad. Sci. USA 73: 2520-2523.

Llinás, R., and C. Nicholson (1971) Electrophysiological analysis of alligator cerebellar cortex: A study on dendritic spikes. In Neurobiology of Cerebellar Evolution and Development, R. Llinás, ed., pp. 431-465, American Medical Association, Chicago, IL.

Llinás, R., and M. Sugimori (1980a) Electrophysiological properties of in vitro Purkinje cell somata in mammalian cerebellar slices. I. Physiol. (Lond.) 305: 171-195.

Llinás, R., and M. Sugimori (1980b) Electrophysiological properties of in vitro Purkinje cell dendrites in mammalian cerebellar slices. J. Physiol. (Lond.) 305: 197-213.

MacDermott, A., M. Mayer, G. Westbrook, S. Smith, and J. Barker (1986) NMDA-receptor activation increases cytoplasmic calcium concentration in cultured spinal cord neurones. Nature 321:519-522.
MacDonald, R., G. Moonen, E. Neale, and P. Nelson (1982) Cerebellar macroneurons in microexplant cell culture. Postsynaptic amino acid pharmacology. Dev. Brain Res. 5: 75-88.

Mayer, M., and G. Westbrook (1984) Mixed-agonist action of excitatory amino acids on mouse spinal cord neurones under voltage clamp. J. Physiol. (Lond.) 354: 29-53.

Meech, R. (1978) Calcium-dependent potassium activation in nervous tissues. Annu. Rev. Biophys. Bioeng. 7: 1-18.

Miller, R. (1987) Multiple calcium channels and neuronal function. Science 235: 46-52.

Narahashi, T., A. Tsunoo, and M. Yoshii (1987) Characterization of two types of calcium channels in mouse neuroblastoma cells. J. Physiol. (Lond). 383: 231-249.

Nowak, L., P. Bregestovski, P. Ascher, A. Herbet, and A. Prochiantz (1984) Magnesium gates glutamate-activated channels in mouse central neurones. Nature 307: 462-465.

Quinlan, J., and J. Davies (1985) Excitatory and inhibitory responses of Purkinje cells, in the rat cerebellum in vivo, induced by excitatory amino acids. Neurosci. Lett. 60: 39-46.

Rall, W. (1976) In Handbook of Physiology, E. Kandel, ed., pp. 3997, American Physiological Society, Bethesda, MD.

Regan, L. (1987) Calcium channels in freshly-dissociated rat cerebellar Purkinje cells. Soc. Neurosci. Abstr. 13: 100.

Ross, W., and R. Werman (1987) Mapping calcium transients in the dendrites of Purkinje cells from the guinea-pig cerebellum in vitro. J. Physiol. (Lond.) 389: 319-336.

Schwartzkroin, P., and M. Slawsky (1977) Probable calcium spikes in hippocampal neurons. Brain Res. 135: 157-161.

Schwindt, P., and W. Crill (1980) Effects of barium on cat motoneurons studied by voltage clamp. J. Neurophysiol. 44: 827-846.

Tank, D., M. Sugimori, J. Connor, and R. Llinás (1988) Spatiallyresolved calcium dynamics of mammalian Purkinje cells in cerebellar slice. Science (in press).

Wiklund, L., G. Toggenburger, and M. Cuenod (1982) Selective retrograde labelling of the rat olivocerebellar climbing fiber system with ${ }^{3} \mathrm{H}$-D-aspartate. Neuroscience 13: 441-468.

Wiklund, L., G. Toggenburger, and M. Cuenod (1984) Aspartate: Possible neurotransmitter in cerebellar climbing fibers. Science $216: 78$ 80.

Wong, R., and D. Prince (1978) Participation of calcium spikes during intrinsic burst firing in hippocampal neurons. Brain Res. 159: 385390.

Wong, R., D. Prince, and A. Basbaum (1979) Intradendritic recordings from hippocampal neurons. Proc. Natl. Acad. Sci. USA 76: 986-990. 